\title{
Social magi i håndværksfagene
}

\author{
Marie Debora Koch og Eva Ahlskog-Björkman
}

Det overordnede mål $i$ studiet er at få forståelse for, hvordan baredygtighed som grundlaggende element $i$ sloyd education ${ }^{1}$ kan andre i studerendes aktive sociale og demokratiske deltagelse $i$ det samfund de lever $i$. Målet er endvidere at få en forståelse for, hvordan den sociale dimension som en del af baredygtig udvikling kan relateres til sloyd education. Vores forskningsspфrgsmål er: Hvordan italesatter informanterne den sociale dimension i sloyd education, når baredygtighed er det grundlaggende element? Studiet er sociokulturelt og vi har valgt at udfolde den sociale dimension gennem informanternes fortallinger ud fra lerfigurer som visualiserer baredygtighed $i$ sloyd education. Fortcellingerne analyseres $i$ det aktuelle studie ved brug af den transskriberede tekst fra videooptagelser. Vi gennemforte en fem trins analyse, hvor det første trin var meningskondensering. Andet trin var bestemmelse af forskellige meninger, tredje trin udtrykte det dominerende tema, fjerde trin var at satte de forskellige meninger sammen og se dem i lyset af unders $\phi g e l s e n s$ formål. Og endelig var det femte trin at sammensatte de vigtigste meninger $i$ et selvstandigt udsagn. Vi kommer med bud på hvordan resultaterne, der peger på en overset social dimension $i$ sloyd education, kan bidrage til at udvikle de studerendes fardigheder og kompetencer med det formål at de studerende kan deltage som aktive medborgere i det samfund de lever $i$.

\section{Indledning}

Titlen Social magi i håndvarksfagene er valgt i forlængelse af forskningsresultatet fra et tidligere studie som er beskrevet i artiklen Hållbar utveckling och lärande $i$ slöjd (Koch \& Ahlskog-Björkman, 2019). I studiet undersøgte vi lerfigurer skabt af lærerstuderende som deltog i det nordiske forskernetværk, SELAS, Sloyd Education, Learning and Sustainability - et NordFo Netværk. Lerfigurerne skulle udtrykke hvad bæredygtighed betyder for nordiske studerende der uddanner sig i sloyd education. Denne artikels empiriske grundlag er de studerendes fortællinger om deres lerfigurer.

\footnotetext{
${ }^{1}$ Sloyd education og håndværksfag anvendes parallelt i artiklen som en samlet betegnelse.
} 
I dette studie er begrebet bæredygtighed centralt, og vi læner os op ad betydningen som den er defineret i Den Danske Ordbog (2020): Sikring af holdbare positive resultater uden $\phi$ delaggelse af det foreliggende grundlag, $f x$ miljø eller resurser. Vores studie sætter endvidere fokus på den sociale dimension i læring indenfor sloyd education. Ifølge Illeris (2009) skal læring forstås som både tilegnelse af nye kundskaber og færdigheder, som i vort eksempel er sloyd education, og som drivkraftens betydning. Dette beror på den studerendes motivation og lyst til at forstå egen læring. Illeris fremhæver også den sociale dimension i sit syn på læring. Illeris (2009) fremhæver nemlig læring som en social proces, hvor læring altid foregår i samspil mellem individet og de omgivelser hvori læring foregår.

Vort tidligere studies resultater (Koch \& Ahlskog-Björkman, 2019) peger blandt andet på den sociale vinkel i faget sloyd education. Dog præciserer studiet ikke tydeligt hvilke betydninger man kan læse ud af en sådan social dimension i sloyd education. I artiklen (Koch \& Ahlskog-Björkman, 2019) konkluderer vi at den sociale dimension er særlig væsentlig i dag, når vi sætter fokus på bæredygtighed, eftersom vi mennesker på hele jorden nødvendigvis sammen må tage vare på jordkloden. Vi ser at informanterne gestalter omtanke og lydhørhed i deres lerfigurer når det gælder om at række ud og lytte til hvad der sker i samfundet. Mennesket placeres således både i et lokalt og et globalt fællesskab. Det vi ikke ser i ovennævnte studie (2019) er hvad denne omtanke og lydhørhed betyder for det enkelte individs aktivitet og handlen. Vi er derfor interesserede $\mathrm{i}$ at udforske og uddybe hvad informanterne italesætter om den sociale dimension. Det vil sige, at vi stræber efter at få en forståelse af hvordan den sociale dimension som en del af en bæredygtig udvikling - kan relateres til sloyd education. Det overordnede mål er at synliggøre hvordan bæredygtighed som grundlæggende element i sloyd education kan ændre de studerendes aktive sociale og demokratiske deltagelse i det samfund de lever i.

Vi stiller følgende forskningsspørgsmål: Hvordan italesætter informanterne den sociale dimension i sloyd education når bæredygtighed er det grundlæggende element?

Denne artikel handler således om hvad de studerende fortæller om hvad de vil kommunikere gennem deres lerfigurer, med tanke på FN:s verdens mål (Agenda 2030) og Greta Thunbergs kommunikative aktion Skolstrejk för klimat (Thunberg, Thunberg, Ernman \& Ernman, 2019). Ideen til at bede informanterne om at udtrykke sig gennem lerfigurer, fik vi fordi vi så hvor stor en kraft der ligger i Greta Thunbergs enkle kommunikative budskab om at stå fælles om at indtænke bæredygtighed. Vi har i vores studie bedt informanterne om at italesætte deres budskab enkelt og præcist gennem at skabe en lerfigur der 
kommunikerer bæredygtighed. Analysen af hvad informanterne og deres lerfigurer fortæller kan muligvis føre os dybere ind i vores søgen efter hvad informanterne italesætter om sociale vinkler på bæredygtighed i sloyd education. De studerendes fortællinger analyseres i det aktuelle studie ved brug af transskriberet tekst fra videooptagelser. Fortællingerne handler om betydning og mening, udtrykt i de studerendes lerfigurer.

\section{Hvordan kan håndens arbejde blive til et sprog om bæredygtighed?}

Giddens (1997) beskriver samfundet frem mod det tredje årtusind som et samfund i stadig forandring, mere differentieret og med øget fokus på den enkelte borgers eget ansvar for at skabe sig en identitet. Fra kulturstudier (Foucault, 1993; Giddens, 1997; Scott Sørensen, 2010) ved vi, at individet er formet af kulturens diskursive anvisninger i hvordan man kan forhandle sig frem til en legitim position i kulturen. Det betyder at individet fra barndommen lærer dels kulturens koder, dels hvordan det skal agere som et subjekt med andre subjekter (jfr Koch, 2012).

Læring som mulighed og handleform for individet i kulturen bliver uddybet af Illeris' (2009) definition på læring. Det er en kompleks sag at forstå læring som begreb, at definere det og benytte det til at skabe sin egen identitet (Illeris, 2009). Megen nyere forskning definerer læring (Biesta, 2005, 2014; Koch, 2012; Säljö, 2000), og forskellige udsagn er i det følgende citeret med henblik på en forståelse og mulig definition af hvad læring er. Säljö $(2000,2008)$ mener ud fra en sociokulturel synsvinkel at læring grundlæggende handler om hvad individer og kollektivet tager med sig fra forskellige sociale situationer og bruger i fremtiden. Säljö (2000) mener desuden at læring sker i samspil mellem individ og kollektiv og imellem individ og institutioner. I forlængelse af Säljö falder valget naturligt på den forskning der rummer læring i både uformelle som formelle rum (Koch, 2012).

Ifølge Biesta (2005) er læring ikke et produkt eller en færdighed som man tilegner sig og inkorporerer efter individuelt behov. Biesta opfordrer til at man forstår læreprocessen som et muligt svar på en udfordring. Svaret giver individet

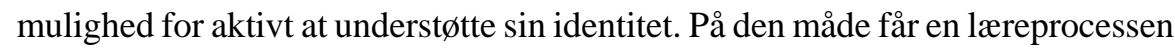
kvalificerende funktion i et bredere sammenhæng (Biesta, 2014). Den socialiserende funktion i læreprocessen handler om medborgerskab og hvordan individet deltager aktivt i samfundet. Biesta (2015; jvf. desuden Scott Sørensen \& Kortbek, 2018) peger på at der findes en grundlæggende forskel mellem dels det sociale, dels det politiske medborgerskab. Det sociale medborgerskab har fokus på medborgerens ejerskab til egen social identitet og til at blive anerkendt 
for samme identitet. Hvorimod det politiske medborgerskab handler om hvorvidt medborgeren er i stand til at sætte sin identitet på spil.

Vi forstår Biesta således at medborgeren, her eleven/den studerende, har muligheder for at anvende sine kompetencer dels gennem identitet, dels gennem aktivitet. Går vi videre til uddannelse og undervisning har Biesta (2015) desuden identificeret tre dimensioner som al undervisning inkluderer: kvalifikation, socialisering og subjektivering. Disse tre begreber rummer forskellige kompetencer til at være til stede i et samfund som individ. Kvalifikation, socialisering og subjektivering handler samlet om at overføre og tilegne sig viden og færdigheder, som er vigtige for at kvalificere de studerende til at handle og gøre noget. Denne handling fører frem imod at være ansvarlig, moralsk og selvstændig (jvf. Sæverot, 2020).

Forskning viser også at læring i sloyd education og identitetsudvikling kan kobles sammen (Ahlskog-Björkman, 2007; Koch, 2012; Mäkelä, 2011), og at begge dele kan indeholdes i æstetiske læreprocesser. Undervejs i den æstetiske læreproces hen imod det færdige artefakt søger det skabende individ efter mening som kan skabe ny indsigt (Karlsson Häikiö, 2012). Den æstetiske læreproces skal i denne sammenhæng forstås som en vekselvirkning mellem individuelle erfaringer og det kollektivt betydningssystem, som FN:s globale mål er et diskursivt udtryk for (Agenda 2030). Denne diskurs kan være vanskelig at begribe konkret, eftersom bæredygtig udvikling altid - både som objekt og i praksis - er kædet sammen med en social kontekst. Det er i forskellige sociale sammenhæng at bæredygtig udvikling bliver til (Agenda 2030; Koch \& Ahlskog-Björkman, 2019; Sørensen, 2010). Håndværksfagenes artefakter kan kommunikere på tværs af forskellige kulturer, love og regler, samtidig med at de altid skal ses i den givne kontekst de optræder i. Forskning indenfor sloyd education viser i $\varnothing v$ vrigt, at der er en tydelig kommunikation mellem materiale og elevernes læreprocesser (Johansson, 2002).

Flensborg (2009, s. 179-181) har udviklet en pædagogisk model for æstetisk erkendelsesproces der gælder i en pædagogisk proces. I modellen er individ, materiale og artefakt involveret på følgende måde:

1. skaber forbindelse mellem kulturformer og individuelle variationer heraf

2. skaber erkendelse

3. skaber bevidsthedsændring gennem refleksion over form (aktiv formgivning)

4. skaber individuelle erfaringer, der fører til forandring i det kollektive betydningssystem 
Ifølge Flensborg (2009) begynder den æstetiske læreproces med at individet indsamler sine erfaringer for at tolke og forstå begrebsligt. De æstetiske læreprocesser fortsætter dernæst ind i en operativ fase (Flensborg, 2009). I modellen ses en proces, der starter med at individuelle erfaringer møder det kollektive betydningssystem.

I et tidligere studie udviklede vi en didaktisk model for læring i sloyd education og bæredygtighed (Koch \& Ahlskog-Björkman, 2019). Modellen er inspireret af Suojanens og Kyrös modell (Suojanen, 2001, s. 262-265) og i dette studie er vor model (se figur 1) videreudviklet i en sammenhæng som både inkluderer Biestas $(2005,2014)$ og Flensborgs (2009) tanker om læring i det samfund vi lever i. I det følgende argumenterer vi for anvendelse af modellen, se nedenfor.

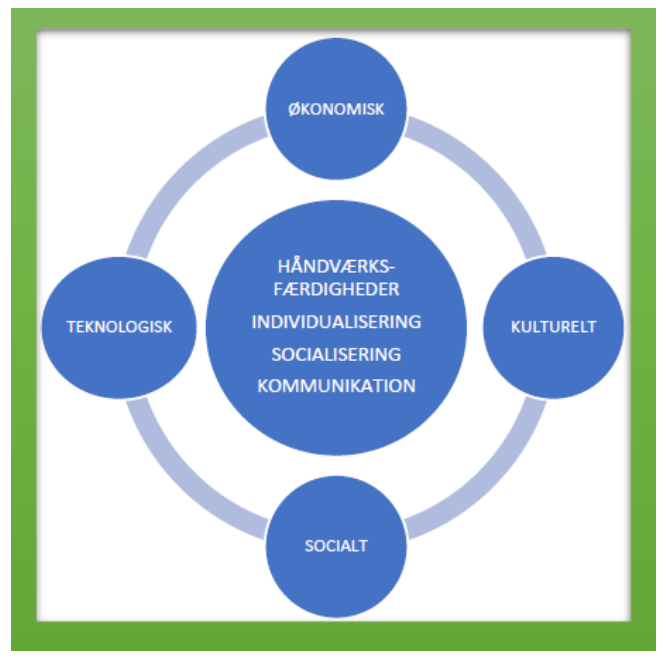

Figur 1. Model for læring og erkendelse i sloyd education og bæredygtighed (videreudviklet efter Koch \& Ahlskog-Björkman, 2019).

Modellen skal læses således at centrum er undervisning, lære- og erkendelsesproces, der relaterer til det omkringliggende samfund, lokalt og globalt. Relationerne er alle koblet til kulturel diversitet og inspireret af FN:s verdensmål (Agenda 2030). I modellen omkranser begrebet bæredygtighed (grøn firkant) erkendelsesprocessen (blå) håndværks færdigheder, individualisering, socialisering og kommunikation. Udenom erkendelsesprocessen drejer samfundet (blå) italesat gennem Teknologisk, Økonomisk, Kulturel og Social Bæredygtighed. 


\section{Informanternes fortællinger om sociale dimensioner $\mathbf{i}$ håndværksfagenene}

Studiet er sociokulturelt (Säljö, 2000) og vi har valgt at udfolde den sociale dimension gennem informanternes fortællinger om artefakterne (Brinkmann \& Tanggaard, 2010). Vi vil i dette studie udforske den sociale dimension og betydningen af aktivitet og handlen ved at stille forskningsspørgsmålet: Hvordan italesætter informanterne den sociale dimension i sloyd education når bæredygtighed er det grundlæggende element?

Det empiriske studie blev gennemført under et SELAS netværksmøde der blev afholdt på Københavns Professionshøjskole, november 2019. På mødet deltog 10 håndværks studerende, to fra Finland, to fra Norge, fire fra Danmark, og to fra Island. Desuden deltog 6 undervisere fra nordiske håndværksuddannelser, tre fra Danmark, en fra Finland, en fra Sverige og en repræsentant fra den samiske befolkning i Norge. Studiet blev ledet af artiklens forfattere, begge forskere. Inden vi alle samledes i København havde forskerne bedt deltagerne om at svare på spørgsmål og forskerne havde desuden bedt de deltagende lærerstuderende om at interviewe mindst fem af deres medstuderende. Spørgsmålene lød således: 1 . Hvorledes er min vision og mission i relation til baredygtighed? 2. Hvorfra kommer jeg? 3. Hvad underviser eller forsker jeg i/ hvad studerer jeg? 4. Hvad vil jeg med mit job/studie? 5. Hvorledes underviser jeg $i$ kunst og håndvark set $i$ relation til baredygtig udvikling? Vi havde indenfor SELAS netværket forinden valgt relevante mål ud fra FN:s globale mål og de mål var grundlaget for de fem ovenstående spørgsmål (FN:s delmål 4,7, og 12, Agenda 2030).

Deltagerne medbragte svarene på de fem spørgsmål og hang dem op på en opslagstavle, kategoriseret efter nationalitet. Det fremgik af svarene hvad der var væsentligt $\mathrm{i}$ forhold til sloyd education og bæredygtighed. Derefter fik samtlige deltagere til opgave at visualisere og karakterisere en "prototype" på en bæredygtig persona. Lerfigurerne skulle udtrykke hvad bæredygtighed betyder for deltagerne hver især. Materialet var billedhugger ler. Forskerne valgte figuren som udtryksform, eftersom vores informanter sædvanligvis arbejder med andre materialer end ler i sloyd education. Udgangspunktet skulle være at materialet var lige ubekendt for alle. Under arbejdet med figurerne skrev informanterne noter og når alle figurerne var færdige, fortalte informanterne en efter en hvad deres figur forestillede og udtrykte. Informanternes fortællinger blev filmet med video. Transskribering af videomateriale danner grundlag for denne artikel. De studerendes fortællinger analyseres i det aktuelle studie ved brug af den transskriberede tekst fra videooptagelser. Fortællingerne handler om betydning og mening, udtrykt i de studerendes lerfigurer. Vi gennemførte en fem trins analyse hvor det første trin var meningskondensering. Andet trin var 
bestemmelse af forskellige meninger, tredje trin udtrykte det dominerende tema, fjerde trin var at sætte de forskellige meninger sammen og se dem i lyset af undersøgelsens formål. Og endelig var det femte trin at sammensætte de vigtigste meninger $i$ et selvstændigt udsagn (Kvale \& Brinkmann, 2015). I analysen fremkom følgende kategorier: A. om samarbejde lokalt og globalt, B. om at tage etisk ansvar, C. om at tage ansvar for det materielle, D. om at tage ansvar for at kommunikere.

\section{A. Om samarbejde lokalt og globalt}

Informanterne siger at de ser sloyd education som både et lokalt og frem for alt et globalt samarbejde, hvilket peger på at den sociale dimension har en betydning. Informanterne taler om samarbejde både lokalt og globalt som en nødvendhed i modsætning til at stå alene.

Vi har nu gjort det sammen, for vi tænkte ligesom, at for én person er det svært at påvirke og gøre nogle ting stort. Men (når vi gør det) sammen bliver det lettere, og det føles, som om at én person alene har svært ved at påvirke den holdbare fremtid. FI

I was thinking how important everybody in the world is and hold our... that we have our hands together on the earth. IS

At vi ikke tænker på alene at engagere Norden. Det er et globalt ansvar. Noget, vi skal passe på og tage ansvar for. Det er vores jord - menneskenes. FI

\section{B. Om at tage etisk ansvar}

Informanterne præciserer hvor vigtigt det er at have et etisk blik på ansvar. Informanterne peger på en holistisk tænkning når de udtaler vigtigheden af at vise omsorg for alle levende skabninger i både dyre- og planteriget. Informanterne opfordrer til at tage ansvar for dyr, mennesker og den klode vi lever på.

we are role models for others. IS

Og så skal det forestille en kat, men vi kalder det et dyr. Og bæredygtighed - der skal vi også tænke på andre, der lever på denne planet, og hvordan det påvirker dem. Vi skal tænke på dem - på dyrene også. Ja menneskene er ikke de eneste som lever på denne jord. Vi må også tænke på alt andet liv på jorden. FI

\section{Om at tage ansvar for det materielle}

Foruden at tage ansvar for alt levende peger informanterne på ressourcer, konsumering og materialer. Informanterne taler om ansvar for ressourcer når de fremhæver hvordan mennesket bruger klodens ressourse-rigdom. 
Og det er dét her, vi skal forbruge nu. Og det er dét, vi skal forbruge fremover, (figurerne, som hun holder i højre hånd, symboliserer det, vi skal bruge i fremtiden) - Vi skal simpelthen forbruge mindre, derfor er de små. DK

$\mathrm{Vi}$ anvender for mange ressourcer nu, og det er vores ansvar at give det tilbage - i stedet for bare at anvende alt det der findes. FI

Informanterne taler desuden om konsumering, om forbrug og genbrug og om hvordan information og inddragelse af deres medborgere kan være vejen frem mod målet, som er at formindske deres medborgeres lyst til at forbruge.

Hvordan vi end tænker, så kommer vi til at konsumere og købe varer i fremtiden - både inden for skole og uddannelse. Vi kan gøre mennesker medvidende om, hvordan den her virkelighed fungerer... og det er helt og holdent afgørende, mener jeg. Vi skal også kunne konsumere med viden om at forlænge holdbarheden - først og fremmest i fremtidens tekniske udstyr som vi til stadighed vil have brug for. Enten gør vi det selv, eller nogle andre gør det: holder $\emptyset j \mathrm{je}$ med, servicerer, reparerer. Men vi må være vidende om, at det skal gøres. Og jeg vil hævde at både en billig og en dyrere variant kan anvendes længe hvis den håndteres sådan. FI

Informanterne inddrager teknologiens muligheder og farer og diskuterer hvordan vi kan formindske eksempelvis brugen af skadelige materialer som plastik.

man kan lige så godt bruge alt det, der er - alt det teknologiske, der er - fordi f.eks. plastik, det kommer der jo ikke mindre af ved at gå fuldstændig tilbage til det traditionelle. Ved at genbruge plast kan man jo formindske eller genbruge det. DK

\section{Om at tage ansvar for at kommunikere}

Informanterne taler om at kommunikere og med det inddrager de at lytte, at informere og at overlevere traditionsbåren kultur og traditioner. Informanterne eksemplificerer kommunikation som noget der foregår gennem øret og munden hos det enkelte menneske. De lader derefter mennesket inkorporere informationerne og sprede dem ud til andre. Informanterne anvender nøgleord i kommunikation som at viderebringe information, kundskaber og beslutninger $i$ forskellige fora.

Vi kan tage øret. Det handler om at lytte og tage imod informationer. Munden er den, der informerer og beslutter. Den spreder information, andres hensigter og den slags - sådan at de (mennesker) ikke er lukket inde i egen boble. Og så har vi en mund. Den handler om at kunne give info og kundskaber, og informere om måske det, som besluttes; vi tænker helt enkelt på dette her møde og at sprede videre information. FI 
Informanterne inddrager historisk bevidsthed når de taler om det traditionelle, eksemplificeret gennem kendskab til gamle håndværksteknikker. Informanterne knytter det traditionelle til moderne teknologi. Deres konklusion er at de gamle traditionsbundne teknikker ikke kan stå alene i den moderne verden. Teknikkerne skal bevares men også reformuleres i samarbejde med teknologien.

Ja, det handler overordnet om, at det var traditionelle, gamle teknikker, og om at kende de gamle teknikker. Men samtidig også at gå til bekendelse og sige: vi har også den teknologiske udvikling som vi kan koble på. DK

Det traditionelle og det moderne - man kan ikke med alt det, der foregår i verden i dag - kan man ikke gå fuldstændig tilbage til det traditionelle. DK

\section{Konklusion}

Vi vil nu sammenfatte vores resultater med Flenborgs (2009) æstetiske model og dens fire grundsætninger samt med Biestas $(2005,2014)$ tre undervisningsdimensioner kvalifikation, socialisering og subjektivering. Efter sammenfatningen føres konklusionen videre ind i perspektivering (se afsnit nedenfor Hvorfor social magi i håndvarksfagene?), hvor vi beskriver og giver forslag til en konkret didaktisk anvendelse af denne artikels model (se Figur 1) målrettet grundskolen.

I Flensborgs første sætning: Skaber forbindelse mellem kulturformer og individuelle variationer heraf finder vi følgende kategorier A og D. Kategori A, at samarbejde lokalt og globalt betyder for informanterne at arbejdet $\mathrm{i}$ håndværksfagene er globalt frem for lokalt. At arbejde globalt betyder for informanterne at de tager udgangspunkt i det lokale, men at fokus er globalt. Vi ser at den sociale dimension kommer til udtryk, fordi informanterne inkluderer både det nære samarbejde (lokalt) og samarbejde på verdensplan (globalt). Flensborgs sætning om at skabe forbindelse mellem kulturformer og individuelle variationer heraf er udtrykt i dimensionen global ud fra forståelsen af at det enkelte individ - fra det sted, hun befinder sig - ønsker at kommunikere med alle kulturer omkring sig. I kategori $D$, at tage ansvar for at kommunikere peger informanter på kommunikation mellem før og nu, hvilket er en vigtig pointe for at kunne udvikle og bevare den traditionsbundne kultur med det moderne. Billedligt anvender informanterne øret og munden hos mennesket, forstået sådan at hvert menneske indeholder viden og kundskaber som det har mulighed for at dele med andre mennesker. Denne enkle form for kommunikation er en slags spredning af information som passer ind i Flensborg sætning om at skabe forbindelse mellem kulturformer og individuelle variationer heraf.

I Flensborgs anden sætning Skaber erkendelse finder vi kategorierne B, om at tage etisk ansvar, $\mathrm{C}$, at tage ansvar for det materielle og $\mathrm{D}$, at tage ansvar for at kommunikere. I alle tre kategorier ser vi at informanterne fremhæver ansvar 
som en etisk fordring. Ikke alene ansvar for at kommunikere, men også ansvar for alt levende - mennesker, dyr og alt hvad der befinder sig på kloden. I Kategori C, at tage ansvar for det materielle, ses en fremhævning af materialiteten som i sløjd education er grundlaget for at arbejde med hænderne.

Flensborgs tredje sætning Skaber bevidsthedsandring gennem refleksion over form (at skabe $i$ håndvarksfagene) finder vi implicit i alle kategorier: A, om at samarbejde lokalt og globalt; $\mathrm{B}$, om at tage etisk ansvar; $\mathrm{C}$, at tage ansvar for det materielle; $\mathrm{D}$, at tage ansvar for at kommunikere. Informanterne taler om vigtigheden af at bevidstgøre sig i relation til håndværksfaget, når de i alle fire kategorier sætter fokus på samarbejde lokalt og globalt, etisk ansvar for alt levende, ansvar for det materielle og for at kommunikere. Netop i sløjd education arbejder man med kundskaber og viden og skaber gennem forskellige materialer en form som taler til den der ser formen med et andet sprog end det verbale.

I Flensborgs fjerde sætning Skaber individuelle erfaringer, der fører til forandring $i$ det kollektive betydningssystem finder vi alle kategorierne A, B, C og D. Flensborgs fjerde sætning fremhæver forandring i det kollektive betydningssystem, hvilket alle fire kategorier også italesætter. I forhold til denne artikels fokus, den sociale dimension i sloyd education, ser vi at det kollektive betydningssystem er en anden måde at artikulere bæredygtighed, at reflektere. Det betyder at det er nødvendigt at knytte bæredygtighed til dét at tage ansvar, samt at knytte bæredygtighed til det enkelte individs bevidstgørelse om dette ansvar. Vi ser at der findes forudsætninger for forandring i sloyd education.

Biestas $(2005,2014)$ tre undervisningsdimensioner kvalifikation, socialisering og subjektivering handler om at tilegne sig viden og færdigheder som er vigtige for at kvalificere de studerende til at handle og gøre noget. Denne handling fører frem imod at være ansvarlig, moralsk og selvstændig. Vi ser at den viden og de færdigheder, som er indeholdt $i$ kvalifikation, socialisering og subjektivering, er nødvendige i en sloyd education læreproces. Resultaterne er sammenholdt med både Flensborg (2009) og Biesta (2005, 2014), og vi konstaterer at både læreprocesser (Biesta, 2005, 2014) og erkendelser (Flensborg, 2009) er forudsætninger for at det handlende og aktive subjekt kan kommunikere bæredygtighed i sloyd education.

\section{Hvorfor social magi i håndværksfagene?}

Vi anvender ordet magi i betydningen at noget er magisk, hvilket ifølge Dansk Synonymordbog (2020) betyder at noget er fortryllende og forunderligt. Det er forunderligt hvordan den sociale dimension fremstår i sloyd education. Vores resultat viser at den sociale dimension knytter det traditionelle og det moderne sammen, fordi individet får et redskab til at positionere sig som ansvarlig 
medborger. Det sker gennem aktiv handlen, hvilket betyder at tradition gennem praksis, kan anvendes som et nyt sprog. Dette sprog kan eksempelvis bruges til forhandling om bæredygtighed set i en lokal kontekst såvel som en global.

Udfordringen består i at det traditionelle håndværksfag bør tilføres læring i og om at være aktiv social og deltagende i samfundet. Magien skal forstås som en eksponering af det potentiale et traditionsbundet fag indeholder, når det føres ind i den tid vi lever i. Vi bliver nødt til at se de udfordringer i øjnene, som den omgivende verden konfronterer os med. Et magisk eksempel er den svenske aktivist Greta Thunberg, der i al sin enkelthed kommunikerer gennem et papskilt, en handling der i løbet af kort tid er blevet symbolet på en aktiv verdens medborger.

Hvorledes tilføres undervisning i håndværk en social dimension? Som eksempel peger vi på at strikke en vante, hvilket kan være en opgave for elever på begynderplan. Vanten er en traditionel håndværksteknik, funktionel og ofte lokalt forankret i form af farve og mønster. Vanten er ligeledes et eksempel på at det enkle kan tale og kommunikere, ligesom Thunbergs papskilt. Vanten rummer nemlig - set ud fra en samfundsmæssig vinkel - et sprog der overordnet kan tale om individualisering, socialisering og kommunikation (se Figur 1). Vantens historik er en medierende faktor som giver eleven i skolen et redskab til at række ud lokalt og globalt mod vores moderne verden i retning af $\varnothing$ konomisk, socialt, kulturelt og teknologisk, som er de områder der kontektualiserer sloyd educations kundskaber, der er centrum i Figur 1. Vi anvender individualisering, socialisering og kommunikation som didaktiske greb når kundskaber skal formidles i sloyd education på grundlæggende uddannelsesniveau.

Vi opfordrer til at reflektere over hvorledes vanten bruges som et eksempel på et sprog, der giver den enkelte elev mulighed for som individ at kommunikere bæredygtighed via et stykke håndværk. Kommunikationen om bæredygtighed, relateret til vanten, tilfører eleven en ekstra identitet - først som håndværksudøver, dernæst som aktiv kommunikerende medborger. Disse kundskaber kvalificerer eleven til at ændre det traditionelle ved at nytænke den traditionelle sloyd education. Eleven er i denne handling en aktiv og socialt deltagende medborger i det lokale, såvel som det globale samfund.

Når informanterne taler om artefakter med bæredygtighed som et fokuspunkt for lære- og erkendelsesprocessen, så peger de på den sociale dimension. Den sociale dimension karakteriseres ved værdier som samarbejde, etiskt ansvar, ansvar for det materielle, konsumption, materialer, kommunikation, information og ansvar for at forene traditionel og moderne kultur. Disse værdier kan ses som en ny dimension til den traditionelle forståelse af håndværk, som er baseret på 
hjemmeproduktion. Hjemmeproduktionen er social og kulturel, men lokalt forankret og ikke i en stor udstrækning knyttet til teknologi, økonomi og overordnede kulturelle og etiske værdier i samfundet. På den måde udfordres den lokale kultur - i relation til vores tid og FN:s verdensmål (Agenda 2030). Vi ser her at udfordringen for håndværksfagene er at de er forankret lokalt, men mangler den globale forankring til den social og samfundsmæssig dimension. Vi kan konstatere at vores overordnede mål italesættes af informanterne, når de fortæller om hvad deres lerfigurers budskab er. Samtidig er det en understregning af at den sociale dimension, som er en del af bæredygtig udvikling, også er en naturlig del af håndværksfagenes indholdsmassige udvikling.

\section{Referencer}

Ahlskog-Björkman, E. (2007). Textilt skapande som estetisk-etisk transformation - om medierat lärande $i$ vårdutbildning. (Diss.). Åbo: Åbo Akademis Förlag.

Agenda 2030 (https://www.un.org/sustainabledevelopment/). Hämtad 26.10. 2020

Biesta, G. (2005). Against learning. Reclaiming a language for education in an age of learning. Nordisk Pedagogik.

https://www.ltu.se/cms_fs/1.123949!/file/Article+Biesta+against+learning.pdf.

Biesta, G. (2014). "Vi får ikke altid det, vi ønsker os: Et ikke-arkaisk syn på uddannelse, demokrati og dannelse". I Jacob Thorek Jensen og Ida Brændholt Lundgaard (red.). Museer - Viden, demokrati, transformation. København: Kulturstyrelsen: 110-124.

Brinkmann, S. \& Tanggaard, L. (2010). Kvalitative metoder. Viborg: Hans Reitzels Forlag. Den Danske Ordbog (2020). https://ordnet.dk/ddo/ordbog?query=magi hentet 22.10.2020

Den Danske Ordbog (2020). https://ordnet.dk/ddo/ordbog?query=bæredygtighed hentet 11.12.2020

Flensborg, I. (2009). Æstetikmodeller i billedkunst. I K. Fink-Jensen \& A.M., Nielsen (Red.), Astetiske lareprocesser - i teori og praksis, pp. 175-192. Værløse: Billesø \& Baltzer.

Foucault, M. (1993) Diskursens Ordning. Stockholm: Brutus Ôstlings Bokforlag.

Giddens, A. (1997). Modernitet og selvidentitet. Samfundet og samfundet under moderniteten. København: Hans Reitzels Forlag.

Illeris, K. (2009). Laring. Frederiksberg: Roskilde Universitetsforlag.

Johansson, M. (2008). Att tänka med nålen i hand - medierande redskap i slöjdpraktik. I H. Rystedt \& R. Säljö (Red.), Kunskap och människans redskap: teknik och lärande, s. 263-276. Lund: Studentlitteratur.

Karlsson Häikiö, T. (2012). Att vara vid sina sinnen. Kultur, estetik och lärande. I A. Klerfelt \& Qvarsell (Red.), Kultur, estetik, och barns rätt i pedagogiken. Malmö: Gleerups.

Koch, M. (2012). Jag strikker, derfor er jeg. Laring og identitet $i$ uformelle laeringsrom. (Diss.). Åbo: Åbo Akademis förlag.

Koch, M. \& Ahlskog-Björkman, E. (2019). Hållbar utveckling och lärande i slöjd. Nordic Studies in Education. ISSN online 1891-5949, Vol. 39, 3-2019, pp. 185-197. https://doi.org/10.18261/issn.1891-5949-2019-03-02

Kvale, S. \& Brinkmann, S. (2015). Interview. Det kvalitative forskningsinterview som håndvark. København: Hans Reitzels Forlag. 
Mäkelä, E. (2011). Slöjd som berättelse, om skolungdom och estetiska perspektiv. (Diss.). Umeå: Umeå universitet, Institutionen för estetiska ämnen i lärarutbildningen.

Scott Sørensen, A. \& Kortbek, H. (2018). Deltagelse som kunst- og kulturformidling. København: Samfundslitteratur.

Scott Sørensen, A. (Red). (2010). Nye kulturstudier, teorier og temaer. København: Tiderne Skifter.

Suojanen, U. (2001). Hållbar utveckling ur slöjdpedagogisk synvinkel. I E. M. Blomqvist (Red.), Från teknik till etik: miljöförståelse $i$ universitetsperspektiv. Åbo: Åbo Akademis förlag.

Sæverot, A. M. (2020). Bilde og pedagogik. En empirisk unders $\phi k e l s e$ av ungdoms fortellinger om bilder. (Diss.). Bergen: Universitetet i Bergen.

Säljö, R. (2000). Lärande i praktiken. Ett sociokulturellt perspektiv. Stockholm: Prisma

Säljö, R. (2008). Lärande i människans landskap. I H. Rystedt \& R. Säljö (Red.), Kunskap och människans redskap: teknik och lärande. Lund: Studentlitteratur.

Thunberg, G., Thunberg, S., Ernman, B. \& Ernman, M. (2019). Scener fra hjertet. København: Politikens Forlag.

Marie Debora Koch, projektforsker, $\mathrm{PhD}$, Copenhagen Institute of Interaction Design, DK. Min forskningsinteresse er fokuseret på, hvad er det didaktiske subjekt og hvad er relevant for subjektet, set i relation til en social dimension indenfor sloyd education og sloyd science. Jeg er medstifter af SELAS, Sloyd Education, Learning And Sustainability - et NordFo Network, indenfor hvilket min forskning foregår i samarbejde med de øvrige nordiske lande.

Eva Ahlskog-Björkman, PeD, docent i pedagogik med inriktning mot estetik, konst och skapande vid Fakulteten för pedagogik och välfärdsstudier vid Åbo Akademi, Vasa Finland. Eva har arbetat som lärarutbildare och forskare. Hennes forskningsområde är estetik och lärande speciellt inriktat mot barns skapande i bild och slöjd i förskola och åk 1-2 i den grundläggande utbildningen. Forskningsintresset är dessutom fokuserat på hållbar utveckling i relation till slöjd samt professionsutveckling inom området för estetik, konst och skapande inom olika utbildningssammanhang. 
Slöjdkunnande i förändring - Slöjdkunnande: utmaningar och återupptäckter 